\title{
And now the book reviews ...
}

\section{ITEMS FOR DISCUSSION}

On every agenda of the Editorial Board meetings, Book Reviews appears as an item and occasions considerable comment and criticism, some pats on the back, but at the end of the day the Reviews Editors are left to pick up the pieces and try to do better.

\section{Reviewers}

Certain books are of obvious significance and we always choose a senior reviewer with expertise in the area. But the majority of titles do not come into this category and so decisions have to be made. The safe route is to use a limited number of reviewers who are sound and reliable with deadlines, but who tend to be predictable in what they will say. We feel that more excitement is generated by including some new, usually junior, people known through their research, writing or speaking at meetings. Obviously, this is a strategy with risk: we have hits and we have misses. A related issue is our feeling that being asked to do a book review is an honour much appreciated by psychiatrists in training (it certainly was by us) and which, if they have interesting things to say, gets them known to a wider audience.

\section{Style}

The simplistic comparison is between the journalistic and 'interesting' $v$. the academic and 'dull'. Extremes like this are only moderately helpful, but the best reviewers seem to be able to combine these elements. What is often forgotten when the Journal reviews are compared with book reviews in the broadsheet newspapers is that they are written by practised professionals. Also the hidden hand of the sub-editor may have entered.

\section{Responsibility to authors}

Anyone who has either written or edited a book knows the hours of work involved.
Reviewers should respect this. Not that reviews should not be critical - they should, but they should not be offensive. Authors expect their work to be taken seriously.

\section{Responsibility to readers}

Here decisions as to the choice of book enter and our feeling is that all sub-specialities should be represented and any book likely to interest a significant percentage of that speciality should be reviewed. Where we are uncertain we often ask known experts for advice: "Is this book worth a review? If so, will you do it or suggest a reviewer to us?" In fact, we have become more selective with time. We now receive about 35 books each month, sending out about 15 for review and ordering perhaps three a month extra. One dilemma is whether to review the occasional topical or fringe books that are sent to the Journal. An example would be to reflect the great interest, not restricted to lay persons, in alternative therapies. Do 'interesting' books with a general medical focus make enjoyable Christmas or summer reading? Decisions like this involve us in subjective choices and perhaps we should be more adventurous. Or should reviewing be more tightly constrained by the principles of evidence-based medicine?

\section{Length}

Always a vexed issue. The quality of a review seldom relates to its length: long reviews may bumble on, short reviews may be absolutely to the point. Given space limitations, we feel a mix is the most appropriate together with very brief pieces such as 'What's new in the third edition?' and 'Books received in the office'.

Longer reviews are often the most rewarding for the reader. A sad reflection of the pressure under which National Health Service consultants and university academics work is that their attention is heavily taken up with their clinical work, research and committees; a long review, especially of a complex book, takes up more time than they are able to give.

\section{The future}

Breaking up text with illustrations is a new development. Perhaps we should be reviewing videos, CD-ROMs and websites? Should reviews be published on the internet, allowing for immediacy and stimulating discussion? What then the role of editors?

Comments and ideas please.

Sidney Crown, Alan Lee Reviews Editors, The British Journal of Psychiatry, The Royal College of Psychiatrists, 17 Belgrave Square, London SWIX 8PG

Rosalind Ramsay Reviews Editor, Psychiatric Bulletin, The Royal College of Psychiatrists, 17 Belgrave Square, London SWIX 8PG

\section{A REVIEW OF REVIEWING}

The Trade Union of Book Review Editors is a small one, but as a card-carrying member (I fulfil the same function for Psychological Medicine as do Alan and Sidney for the Journal and Ros for the Psychiatric Bulletin) the first thing to say is how much I sympathise with your Reviews Editors in their task. The journals and their readers owe them a debt of gratitude for all the work they have done over the years.

Why do we do it? What is the purpose of a review? For publishers it is to obtain publicity and sell copies - I have met publishers who feel there is no such thing as a bad review. For authors it is to receive the recognition and appreciation they feel they deserve for their labours. For some reviewers, as Crown et al point out, it is a first dip in the water of writing.

But what about the person for whom a review is intended - the reader? I feel that a review should inform, entertain and occasionally provoke. A review which simply lists the contents of the book in question and draws attention to the (usually exorbitant) price fails in this duty, being little more than a repetition of the publisher's catalogue. Too often overworked reviewers fall back on clichés such as "too expensive for the trainee, but should be in every hospital's library". I doubt if there ever 
was a golden age when hospitals had libraries which bought books on the basis of reviews - they certainly do not now.

The best reviews, which one encounters in such august publications as The Times Literary Supplement or the New York Review of Books, are often jewels of argument and exposition, essays in their own right. The book (or more often books) is but the starting point of the reviewer's journey: at the end the reader is left wiser than before and is often entertained en route.

Most of us have neither the time nor the skill to aspire to these heights. Sometimes we make it - the 'Reading About' section, or the now defunct 'Books Reconsidered' feature and 'Review of Books' supplement, are reviews that I certainly enjoy and read with pleasure. Anthony Maden's review of Inquiries After Homicide in the November issue of Psychological Medicine and the January 2000 Psychiatric Bulletin is another example of reviewing at its finest. But these are rare - why?

First, unlike the $T L S$, we do not pay. Second, we are too polite - bad reviews, if done with wit and style, are more readable than good ones. But the most important reason for the generally low quality of scientific and medical reviews is the nature of the beast itself - scientific publication. Books are not very important for us. Unlike our colleagues in the humanities, scientists do not usually communicate by books. Original research is presented in the learned journals, and books count for nothing in the Research Assessment Exercise which dominates the waking and even sleeping hours of academics. Medical and science books sell exceptionally badly, unless they are written by stylists such as Stephen Jay Gould or Matt Ridley, or alternatively have titles such as Know Your Own Food Allergy. For the rest the combination of too many titles each of which sells too few copies means that there is not the time, money or incentive for any to receive editorial attention and improvement. Textbooks for undergraduates are an exception because of their large market, but even if better written, rarely produce good reviews. Much medical publishing - the interminable conference proceedings or edited books - is both unreadable and unreviewable unless one is a master of satire.

What about the future? With the growth of electronic publishing and bookselling, readers and publishers will be coming ever closer together. If I want to find out what is new in the field of schizophrenia, I will be able to access a list of titles with ease. Readers are going to want more 'added value' from book reviews, just as electronic publication and PUBMED will force traditional journals to be more than collections of original research papers if they are to survive.

In their piece the editors wonder about 'evidence-based' reviews - but anyone who has seen the 'structured' book reviews now used by Annals of Internal Medicine will surely reject this idea. I am an aficionado of evidence-based virtually anything, except book reviews. Instead, let us have fewer, but longer reviews. Let us support better those who can write powerful, interesting and provocative reviews - let us even pay them for their trouble. But most of all, please support your local book review editor - it is a thankless task!

Maden, A. (2000) Inquiries After Homicide (book review). Psychiatric Bulletin, I4, 37-39

Simon Wessely Epidemiology \& Liaison Psychiatry, Maudsley Hospital, Denmark Hill, London SE5 8AZ 